archives-ouvertes

\title{
Chemical composition, antioxidative, antimicrobial and anti-cancer activities of Asteriscus graveolens (Forssk) essential oil
}

\author{
Hadjer Aouissi, Nadhir Gourine, Hong Wang, Xiaochun Chen, Isabelle
} Bombarda, Messaoud Boudjeniba, Mohamed Yousfi

\section{To cite this version:}

Hadjer Aouissi, Nadhir Gourine, Hong Wang, Xiaochun Chen, Isabelle Bombarda, et al.. Chemical composition, antioxidative, antimicrobial and anti-cancer activities of Asteriscus graveolens (Forssk) essential oil. Oriental Pharmacy and Experimental Medicine, Spiringer Link, 2018, 18 (3), pp.217 223. $<10.1007 /$ s13596-018-0315-0 $>$. <hal-01930283>

\section{HAL Id: hal-01930283 \\ https://hal-amu.archives-ouvertes.fr/hal-01930283}

Submitted on 21 Nov 2018

HAL is a multi-disciplinary open access archive for the deposit and dissemination of scientific research documents, whether they are published or not. The documents may come from teaching and research institutions in France or abroad, or from public or private research centers.
L'archive ouverte pluridisciplinaire HAL, est destinée au dépôt et à la diffusion de documents scientifiques de niveau recherche, publiés ou non, émanant des établissements d'enseignement et de recherche français ou étrangers, des laboratoires publics ou privés. 


\title{
Chemical composition, antioxidative, antimicrobial and anti-cancer activities of Asteriscus graveolens (Forssk) essential oil
}

\author{
Hadjer Aouissi ${ }^{1} \cdot$ Nadhir Gourine $^{1}\left[\right.$ [D $\cdot$ Hong Wang $^{2} \cdot$ Xiaochun Chen $^{2} \cdot$ Isabelle Bombarda $^{3} \cdot$ Messaoud Boudjeniba $^{4}$. \\ Mohamed Yousfi ${ }^{1}$
}

\begin{abstract}
This work is devoted to the study of the chemical composition and the evaluation of the biological activities of essential oils (EOs) extracted from the flowers of Asteriscus graveolens Forssk. plant. The EO sample was obtained by hydrodistillation and the chemical composition analysis was performed using GC and GC/MS. The major chemical components characterizing the EO were cis-chrysanthenyl acetate (44.30\%) and cis-8-acetoxychrysanthenyl acetate (33.70\%). Antioxidant activity was determined using DPPH and Phosphomolybdenum tests. Although the EO presented a weak scavenging activity (420.16 mg/ $\mathrm{mL})$, it exhibited good reducing power using the Phosphomolybdenum assay (0.28 AAEC/mg). The most important antibacterial activity was noted for Bacillus cereus. The oil revealed a remarkable activity against the nine fungi species tested with percentage inhibition up to $94.12 \%$ for Fusarium culmorum (BTCR). More important, this work investigated for the first time the anticancer effect of this EO on two types of cancer cell lines (human liver carcinoma and Rat pheochromocytoma cell lines). The EO showed a high anticancer activity against both tumor cell lines comparing to the positive control.
\end{abstract}

Keywords Asteriscus graveolens Forssk · Essential oil · Chemical composition · Antioxidant activity · Antimicrobial activity $\cdot$ Anticancer activity

\section{Introduction}

The biological properties of natural products as essential oils (EOs) are studied to search a new drugs, antibiotics and pesticides (Buchanan et al. 2000). They have been screened for their potential uses as alternative remedies for the treatment

Nadhir Gourine

gourine.nadir@gmail.com

$\triangle$ Mohamed Yousfi

yousfim8@gmail.com

1 Laboratory of Fundamental Sciences, University of Amar TÉLIDJI of Laghouat, Laghouat, Algeria

2 The College of Pharmaceutical Science and Collaborative Innovation Center of Yangtze River Delta Region Green Pharmaceuticals, Zhejiang University of Technology, Hangzhou, China

3 CNRS, IRD, IMBE, Univ. Avignon, Aix Marseille Univ., Marseille, France

4 Laboratoire d'Éthnobotanique et Substances Naturelles (LESN), École Normale Supérieure (ENS) - Kouba, Algiers, Algeria of many infectious diseases and the preservation of food from the toxic effects of oxidants.

With the emergence of antibiotic-resistance, a reliable alternative to antibiotics is the use of EOs. These compounds are known for their antibacterial properties which have been demonstrated in vitro and in vivo (Zhiri 2006). Many works were devoted for the study of biological properties of EOs, thus, the antimicrobial activity of oils extracted from thyme; rosemary and chamomile were demonstrated (Bakkali et al. 2008; Dorman and Deans 2000; Floris et al. 1996; Marino et al. 2001). Because of the possible toxicities of the synthetic antioxidants, increasing attention has been directed toward natural antioxidants (Avlessi et al. 2004). The antioxidant activity of essential oils has been the subject of much intensive research because of their uses as preservatives in food industry even at low concentrations (Cabrera and Prieto 2010).

Fungal plant pathogens cause many damages to food production and storage. They may be at the origin of catastrophes in which large areas planted to food crops are destroyed (Strange and Scott 2005). In order to combat the losses they cause, it is necessary search remedies. Many studies have 
been devoted to the antifungal activity of EOs and revealed an important effect especially against phytopathogen fungal (Marinelli et al. 2012; Matusinsky et al. 2015; Znini et al. 2011).

Cancer belongs to a huge class of diseases, which cause more than $10 \%$ of all human deaths. Many studies showed the potential of the constituents of essential oil on several cancer cell lines (Adorjan and Buchbauer 2010).

Asteriscus graveolens Forssk (syn. Nauplius graveolens Forsk, Bubonium graveolens Forsk Maire) belongs to the Asteraceae family of herbs. It's very common in the North Africa. Their leaves are collected in the spring, they are prepared as infusion or decoction; the sap of the fresh leaves is used as drops for the nose and poultice for headaches. Traditionally, it is used for blennorrhagia, diabetes, diarrhea, facial neuralgia, head cold, gastralgia, pulmonary problems and sinusitis (International Union of Conservation of Nature IUCN 2005).

In the present work, we report the results of a study aimed to define chemical composition and to evaluate antioxidant, antibacterial, antifungal and for the first time the anticancer activity of $A$. graveolens EO.

\section{Materials and methods}

\section{Plant material and essential oil extraction}

The aerial part of $A$. graveolens was collected from south of Algeria, during the month of June 2013 at the flowering stage. It was identified at the National Institute of Agronomy "INA Institut National d'Agronomie". The separation of the flowers from the aerial parts was executed manually and with care. Then the air drying of the plant material was performed in the shade at room temperature for 10 days. The dried plant sample (flowers) was subjected to hydrodistillation using a Clenvenger type apparatus for $3 \mathrm{~h}$. The distilled EO was dried over anhydrous sodium sulfate and stored at $+4{ }^{\circ} \mathrm{C}$ until use.

\section{Gas chromatography and GC/MS analysis}

An Agilent technologies 7890A gas chromatograph (GC) equipped with a flame ionization detector (FID) was used for compound separations with a HP5 capillary column (30 m $\times 0.32 \mathrm{~mm}$, film thickness $0.40 \mu \mathrm{m})$. The oven temperature program was as follows: $2 \mathrm{~min}$ at $80{ }^{\circ} \mathrm{C}$, from 80 to $200{ }^{\circ} \mathrm{C}$ at $5{ }^{\circ} \mathrm{C} / \mathrm{min}$, then $5 \mathrm{~min}$ at $200{ }^{\circ} \mathrm{C}$, then from 200 to $260{ }^{\circ} \mathrm{C}$ at $20{ }^{\circ} \mathrm{C} / \mathrm{min}$, then $5 \mathrm{~min}$ at $260{ }^{\circ} \mathrm{C}$. Detector and inlet temperatures were $280^{\circ} \mathrm{C}$. Hydrogen was used as carrier gas at a constant flow of $1 \mathrm{~mL} / \mathrm{min}$ with a split ratio 1:70. A volume of $1 \mu \mathrm{L}$ of EO diluted in dichloromethane was injected manually. The retention indices of constituents were calculated relative to a series of $n$-alkane standards $n-\mathrm{C}_{8}-\mathrm{C}_{26}$.

The GC/MS analysis of the EO was carried out on an Agilent HP-6890 coupled to 5973 mass spectrometer and equipped with UB-WAX capillary column $(30 \mathrm{~m} \times 0.25 \mathrm{~mm}$, film thickness $0.25 \mu \mathrm{m})$ and quadrupole detector $(70 \mathrm{eV})$. The carrier gas flow (Helium) was fixed at $1 \mathrm{~mL} / \mathrm{min}$. The transfer line and injector temperatures were fixed at 220 and $250{ }^{\circ} \mathrm{C}$, respectively. $1 \mu \mathrm{L}$ of diluted EO in ethanol solution $(1: 100, \mathrm{v} / \mathrm{v})$ was injected manually in a splitless mode.

Identification of components was based on comparison of their mass spectra with those of WILEY and NIST Libraries as well as on comparison of their retention indices with literature.

\section{Antioxidant activity}

\section{DPPH assay}

In the presence of a proton donor substance, the free radical DPPH takes the non-radical form and loses its purple color (Molyneux 2004). One milliliter of EO dilution in ethanol solvent was added to $1 \mathrm{~mL}$ of $200 \mu \mathrm{M}$ DPPH solution prepared in ethanol solvent. After incubation for $30 \mathrm{~min}$ in a dark, the absorbance was measured at $517 \mathrm{~nm}$ against a blank (ethanol). Decreasing the absorbance of DPPH indicates an increase in DPPH radical scavenging activity, which is calculated according to the equation:

$I \%=\left[\frac{A_{0}-A_{1}}{A_{0}}\right] \times 100$

where $A_{0}$ is the absorbance of the control and $A_{1}$ is the absorbance of the sample.

Control was prepared by a mixture of $1 \mathrm{~mL}$ of DPPH solution and $1 \mathrm{~mL}$ of ethanol. The sample concentration providing $50 \%$ of radical scavenging activity $\left(\mathrm{IC}_{50}\right)$ was determined through the curves obtained. The lower $\mathrm{IC}_{50}$ indicates higher radical scavenging activity and vice versa. Ascorbic acid and $\alpha$-tocopherol were used as standards.

\section{Phosphomolybdenum assay}

The reducing power of EO was measured according to the method of Prieto et al. (1999). The principle is based on the reduction of molybdate $\mathrm{VI}$ to molybdate $\mathrm{V}$ in presence of reducing substance, then the molybdate $\mathrm{V}$ form a greencolored complex and the absorbance is measured at $695 \mathrm{~nm}$. An aliquot of $0.2 \mathrm{~mL}$ of EO solution in ethanol was added to $2 \mathrm{~mL}$ of reagent solution $(0.6 \mathrm{M}$ sulfuric acid, $28 \mathrm{mM}$ sodium phosphate, and $4 \mathrm{mM}$ ammonium molybdate). The tubes were sealed and incubated in water bath at $70{ }^{\circ} \mathrm{C}$ for $90 \mathrm{~min}$. After the incubation period, and when the samples 
had cooled to room temperature, the absorbance of the aqueous solution of each was measured at $695 \mathrm{~nm}$ against a blank containing $2 \mathrm{~mL}$ of reagent solution and $0.2 \mathrm{~mL}$ of ethanol. The antioxidant capacity was expressed as equivalents of ascorbic acid AAEC.

\section{Antibacterial activity}

\section{Bacterial strains}

For the determination of the antibacterial activity of the EO, we used standard and isolated strains of the following Gram-positive bacteria: Bacillus cereus ATCC 12778, Enterococcus faecalis ATCC 29212, Staphylococcus aureus ATCC 29213, MRSA ATCC 43300. The EO was also tested on Gram-negative bacteria: Escherichia coli ATCC 25922, Klebsiella pneumonia ATCC 700603, Pseudomonas aeruginosa ATCC 27853, Salmonella typhi (isolate). The microorganisms were obtained from the culture collection of the "Regional Veterinary Laboratory" and the "Medical Analysis Laboratory of the hospital of Laghouat".

\section{Disc diffusion method}

This method was employed to evaluate the antibacterial activity (Bekhechi et al. 2008). All bacterial strains were first grown on nutrient agar plates at $37^{\circ} \mathrm{C}$ for $18-24 \mathrm{~h}$, prior to inoculation into the nutrient broth. One hundred micro-liter of bacterial suspension containing $10^{8}$ cell $/ \mathrm{mL}$ was spread onto Mueller-Hinton culture medium. A sterile filter disc (diameter $6 \mathrm{~mm}$ ) impregnated with $10 \mu \mathrm{L}$ of the diluted EO in $10 \%$ DMSO (1/4), was placed onto the plate culture. The Petri dishes were stored at $4{ }^{\circ} \mathrm{C}$ for $2 \mathrm{~h}$ and then incubated for $24 \mathrm{~h}$. The diameters ( $\mathrm{mm}$ ) of the inhibition zones were measured. Each experiment was done in triplicate.

\section{Antifungal activity}

Strains of Fusarium culmorum $(124,319)$ and Fusarium graminearum $(156,91)$ was kindly provided by the MycSaINRA of Bordeaux. The strains of $F$. culmorum $\mathrm{T} 7$ and BTCR by Bentouati Sihem mycotheque and Fusarium oxysporum f. sp pisi was obtained from Laboratoiry of mycology, agronomy department of Blida. Fusarium oxysporum f. sp. Albedinis and Fusarium oxysporum f. sp lycopers$i c i$ was provided by the "Regional Station of Plant Protection of Ghardaïa" in Algeria.

Antifungal activity was studied by using contact assay. The EO dilutions in $2 \%$ agar solution was added to the molten PDA medium and poured into Petri dishes (El Ajjouri et al. 2008). The control plate contains PDA added $2 \% \mathrm{w}$ agar solution. A $6 \mathrm{~mm}$ diameter disk of the fungal species was cut from a 1-week-old culture on PDA plates, and then the mycelia surface of the disk was placed upside down on the center of dish.

The incubation was performed at $25{ }^{\circ} \mathrm{C}$ for 7 days. The Extension Diameter (millimeters) of hyphae from the center to the side of the dish was measured and the inhibition percentage was calculated as follows (Aoudou et al. 2010):

$I(\%)=\left(1-\frac{D_{0}}{D_{I}}\right) \times 100$

where $D_{0}$ is an average of 3 replicates of hyphal extension $(\mathrm{mm})$ of controls and $\mathrm{D}_{\mathrm{I}}$ is an average of 3 replicates of hyphal extension $(\mathrm{mm})$ of plates treated with EO.

\section{Anticancer activity}

Cell lines HePG2 (human liver carcinoma) and PC12 (Rat pheochromocytoma cells) were maintained at $37{ }^{\circ} \mathrm{C}$ in a $5 \% \mathrm{CO}_{2}$ atmosphere. Both cell lines were grown in a medium containing $5 \mathrm{~mL}$ of RPMI-1640 supplemented with $10 \%$ fetal bovine serum (FBS).The effect of the EO on cell viability of the two cancer cell lines was determined by 3 [4,5-dimethylthiazol-2-yl]-2,5-diphenyl tetrazoliumbromide (MTT) assay (Mosmann 1983). The growing cells were plated in 96-well microplates at a density of $5 \times 10^{3}$ cells per well in $100 \mu \mathrm{L}$ of culture medium and allowed to adhere for $24 \mathrm{~h}$ before treatment. Increasing concentrations of EO were then added $(100 \mu \mathrm{L} /$ well $)$. The cells were incubated $48 \mathrm{~h}$ in the presence and absence of essential oil. 5-fluorouracil (6.25-100 $\mu \mathrm{g} / \mathrm{mL})$ was used as positive control. $20 \mu \mathrm{L}$ of MTT ( $5 \mathrm{mg} / \mathrm{mL}$ of PBS) were added to each well, and the cells were incubated for a further $4 \mathrm{~h}$. After removal of the medium, $200 \mu \mathrm{L}$ DMSO was added to each well. The absorbance was recorded on a micro plate reader at the wavelength of $490 \mathrm{~nm}$. The effect of the essential oil on cell growth inhibition was assessed as percentage cell growth inhibition. This test was replicated five times.

\section{Results and discussion}

\section{Essential oil composition}

Hydrodistillation of $A$. graveolens flowers yielded $1.16 \pm 0.2 \mathrm{~mL}$ of yellow essential oil upon $100 \mathrm{~g}$ of dry matter.

Forty-two compounds were identified by GC and GC/ MS (Table 1). This analysis showed that the EO contains cis-chrysanthenyl acetate $(44.30 \%)$, cis-8-acetoxychrysanthenyl acetate $(33.70 \%)$ and $\tau$-muurolol $(6.51 \%)$ as major components. The nature of cis-chrysanthenyl acetate and cis-8-acetoxychrysanthenyl acetate was consistent with Cristofari et al.'s study (2012), where the major components 
Table 1 Chemical composition of A. graveolens (Forssk) flowers essential oil

\begin{tabular}{|c|c|c|c|}
\hline & Compound & $\mathrm{LRI}^{\mathrm{a}}$ & Peak area $(\%)$ \\
\hline 01 & $\alpha$-Pinene & 926 & 0.75 \\
\hline 02 & Camphene & 946 & 0.19 \\
\hline 03 & Sabinene & 974 & 0.18 \\
\hline 04 & $\beta$-Pinene & 982 & 0.04 \\
\hline 05 & $\beta$-Myrcene & 991 & 0.34 \\
\hline 06 & $p$-Cymene & 1000 & 0.04 \\
\hline 07 & $\alpha$-Phellandrene & 1010 & 0.03 \\
\hline 08 & Limonene & 1031 & 0.09 \\
\hline 09 & $\alpha$-Terpinolene & 1089 & 0.03 \\
\hline 10 & Linalool & 1097 & 0.06 \\
\hline 11 & $\alpha$-Thujone & 1101 & 0.04 \\
\hline 12 & $\beta$-Ocimene & 1144 & 0.03 \\
\hline 13 & cis-Chrysantenol & 1148 & 0.11 \\
\hline 14 & Menthol & 1165 & 0.36 \\
\hline 15 & Borneol & 1171 & 0.04 \\
\hline 16 & trans-Isopulegone & 1183 & 0.06 \\
\hline 17 & Myrtenal & 1208 & 0.05 \\
\hline 18 & cis-Chrysanthenyl acetate ${ }^{\mathrm{b}}$ & 1270 & 44.30 \\
\hline 19 & Bornyle acetate & 1293 & 0.1 \\
\hline 20 & $\mathrm{NI}$ & 1315 & 0.14 \\
\hline 21 & $\mathrm{NI}$ & 1339 & 0.03 \\
\hline 22 & Eugenol & 1360 & 0.06 \\
\hline 23 & iso-Eugenol & 1455 & 0.03 \\
\hline 24 & $\alpha$-Caryophyllene & 1464 & 0.08 \\
\hline 25 & Aromadendrene & 1471 & 0.26 \\
\hline 26 & $\gamma$-Muurolene & 1485 & 0.07 \\
\hline 27 & Germacrene D & 1491 & 0.18 \\
\hline 28 & $\beta$-Selinene & 1494 & 0.05 \\
\hline 29 & $\mathrm{NI}$ & 1497 & 0.01 \\
\hline 30 & Bicyclogermacrene & 1507 & 0.06 \\
\hline 31 & $\beta$-Bisabolene & 1515 & 0.07 \\
\hline 32 & $\gamma$-Cadinene & 1523 & 0.45 \\
\hline 33 & $\delta$-Cadinene & 1531 & 0.33 \\
\hline 34 & Nerolidol & 1538 & 0.77 \\
\hline 35 & Kessane & 1545 & 0.05 \\
\hline 36 & Calamenene & 1550 & 0.07 \\
\hline 37 & $\mathrm{NI}$ & 1554 & 0.06 \\
\hline 38 & $\begin{array}{l}\text { 3,5,5-Trimethyl-hexahydro-pentalen- } \\
\text { 1-one }\end{array}$ & 1557 & 0.06 \\
\hline 39 & Eudesma-3,7(11)-diene & 1568 & 0.13 \\
\hline 40 & $\mathrm{NI}$ & 1574 & 1.07 \\
\hline 41 & $\mathrm{NI}$ & 1586 & 0.13 \\
\hline 42 & cis-8-acetoxychrysanthenyl acetate ${ }^{\mathrm{b}}$ & 1599 & 33.70 \\
\hline 43 & Methoxy eugenol & 1612 & 0.07 \\
\hline 44 & NI & 1620 & 0.57 \\
\hline 45 & $\mathrm{NI}$ & 1625 & 0.08 \\
\hline 46 & $\mathrm{NI}$ & 1638 & 0.61 \\
\hline 47 & $\mathrm{NI}$ & 1646 & 0.13 \\
\hline 48 & $\tau$-Muurolol & 1652 & 6.51 \\
\hline
\end{tabular}

Table 1 (continued)

\begin{tabular}{llcc}
\hline & Compound & LRI $^{\mathrm{a}}$ & Peak area (\%) \\
\hline 49 & $\alpha$-Eudesmol & 1656 & 0.08 \\
50 & $\alpha$-Cadinol & 1665 & 0.24 \\
51 & $\alpha$-Bisabolone oxide & 1696 & 1.59 \\
52 & Bisabolone & 1756 & 3.61 \\
& Total identified & & 95.36 \\
\hline
\end{tabular}

Bold values represent the main identified chemical components

NI Not Identified

${ }^{\text {a }}$ Retention indices on HP-5 column

${ }^{\mathrm{b}}$ Identified by comparison of obtained mass spectra with those literature (Obtained by Cristofari et al. 2012)

reported were cis-8-acetoxychrysanthenyl acetate (48.5\%) as a new monoterpenic compound, cis-chrysanthenyl acetate $(13.4 \%), \tau$-cadinol (11.4\%) and 6-oxocyclonerolidol (7.8\%). Cheriti et al. (2007) have shown that the chemical composition of flowers essential oil of Bubonium graveolens (Forssk.) (Collected from south-western Algeria) was dominated by 2,6-dimethyl-1,6-heptadien-4-yl acetate (19.4\%), trans-chrysanthenyl acetate (18.7\%), 1,8 cineole (16.5\%) and $\delta$-cadinol (13.9\%). Another study on A. graveolens ssp. odorus revealed that the major components of the aerial parts EO of this plant were 6-oxocyclonerolidol (30.72\%), epi- $\alpha$-cadinol (14.5\%) and $\alpha$-bisabolone oxide (3.56\%) (Alilou et al. 2014). It was found that the chemical composition of the $\mathrm{EO}$ of $A$. graveolens (Forssk.) from this study was quiet different from those of previous works cited above. These differences in the chemical composition could depend on climatic conditions and chemotypes.

\section{Antioxidant activity}

\section{DPPH assay}

The antioxidant capacity of the EO was determined by comparison to the activity of known antioxidants: ascorbic acid and $\alpha$-tocopherol. The assessed EO was able to reduce the stable, purple colored radical DPPH to the yellowcolored DPPH-H reaching $50 \%$ of reduction with an $\mathrm{IC}_{50}$ of $420.16 \mathrm{mg} / \mathrm{mL}$. Comparison of the $\mathrm{IC}_{50}$ of investigated EO with those obtained by ascorbic acid and $\alpha$-tocopherol showed that this EO expressed very weak activity compared to the standards (Table 2). The weak DPPH radical scavenging activity of this oil could be attributed to the absence of active components. When Alilou et al. (2014) studied the antioxidant activity of $A$. graveolens ssp. odorus $\mathrm{EO}$ using DPPH test, they found an important activity expressed as $\mathrm{IC}_{50}$ value of $0.2498 \mathrm{mg} / \mathrm{mL}$, except they used the whole aerial part of this plant which certainly should make the difference in this comparison. 
Table 2 Antioxidant activity of $A$. graveolens (Forssk) essential oils (flowers part)

\begin{tabular}{lcl}
\hline Sample & DPPH assay & $\begin{array}{l}\text { Phosphomo- } \\
\text { lybdenum } \\
\text { assay } \\
\text { (AAEC) }\end{array}$ \\
\hline Asteriscus graveolens & $420.16 \pm 0.01$ & $0.28 \pm 0.01$ \\
Ascorbic acid & $0.0077 \pm 0.0001$ & - \\
$\alpha$-tocopherol & $0.020 \pm 0.001$ & $0.57 \pm 0.02$ \\
\hline
\end{tabular}

\section{Phosphomolybdenum assay}

The results for Phosphomolybdenum assay were presented as equivalents of ascorbic acid per milligram. Higher values indicate better antioxidant activity. The EO showed important value relative to ascorbic acid (Table 2). The activity of the EO of A. graveolens represented about half (roughly) of $\alpha$-tocopherol activity. Vidic et al. (2016) used this method to evaluate the antioxidant activity of some Asteraceae species (Achillea millefolium L., Arnica Montana L., Artemisia absinthium L., and Artemisia annua L.) and the highest antioxidant activity using the Phosphomolybdenum assay was obtained for Arnica Montana L. (55.69 mg AAEC/g).

\section{Antibacterial activity}

The inhibitory effect of $A$. graveolens essential oil on the growth of eight bacterial strains was tested. The EO showed various degrees of antibacterial activity depending on the bacterial strain. As showed in Table 3 the most important activity was observed on $B$. cereus with inhibition diameter of $12.5 \pm 0.50 \mathrm{~mm}$. For the other bacterial strains, the inhibition zone was ranging from 9 to $10.33 \mathrm{~mm}$ (Table 3). According to De Billerbeck (2007) the activity of A. graveolens $\mathrm{EO}$ is intermediate. The antibacterial activity of leaves
Table 3 Antibacterial activity of A. graveolens (Forssk) flowers essential oil

\begin{tabular}{lc}
\hline Bacterial strains & $\begin{array}{l}\text { Diameters of } \\
\text { inhibition zones } \\
(\mathrm{mm})\end{array}$ \\
\hline $1 / 4$ & \\
Escherichia coli & $9.67 \pm 0.58$ \\
Klebsiella pneumonia & $10.33 \pm 0.58$ \\
Salmonella typhi & $9.00 \pm 0.00$ \\
Pseudomonas aeruginosa & $10.00 \pm 0.00$ \\
Bacillus cereus & $12.5 \pm 0.50$ \\
Enterococcus faecalis & $10.00 \pm 0.00$ \\
MRSA & $9.33 \pm 0.58$ \\
Staphylococcus aureus & $9.00 \pm 0.00$ \\
\hline
\end{tabular}

EO of Bubonium graveolens was significant against E. Coli, $E$. faecalis and $S$. aureus, especially against $K$. pneumonia and $P$. aeruginosa comparing with commercial antibiotics (Melekmi et al. 2006).

\section{Antifungal activity}

Table 4 shows the mean radial growth of the fungus species on solid medium containing A. graveolens EO. The mycelial growth diameter of each species was measured during 6 days of incubation. The A. graveolens EO exhibited antifungal activity against the phytopathogenic fungi (Table 4). The percentage inhibition of mycelial growth increased with increasing concentration of EO for all strains tested. The most important activity was noted against $F$. culmorum BTCR with an inhibition growth of $94.12 \%$ corresponding to $20 \mu \mathrm{L} / \mathrm{mL}$ of EO. The inhibitory concentration of $50 \%$ of growth $\left(\mathrm{IC}_{50}\right)$ for the species varied between 0.5 and $1.0 \mu \mathrm{L} / \mathrm{mL}$. This activity could be due to the major component of this EO (cis-chrysanthenyl acetate and
Table 4 Effect of A. graveolens flowers essential oil on Mycelial growth of FOA, FOL, FOP, FG91, FG156, FC124, FC319, T7 and BTCR

\begin{tabular}{lllllll}
\hline \multicolumn{7}{c}{ Percentage inhibition of growth (\%) } \\
\cline { 2 - 7 } & $0.5 \mu \mathrm{L} / \mathrm{mL}$ & $1 \mu \mathrm{L} / \mathrm{mL}$ & $2 \mu \mathrm{L} / \mathrm{mL}$ & $4 \mu \mathrm{L} / \mathrm{mL}$ & $10 \mu \mathrm{L} / \mathrm{mL}$ & $20 \mu \mathrm{L} / \mathrm{mL}$ \\
\hline Fusariumo.f. sp. albedinis & 59.91 & 62.00 & 65.23 & 78.00 & 80.89 & 84.25 \\
Fusariumo.f. sp. lycopercisi & 43.79 & 55.64 & 69.60 & 83.48 & 85.42 & 87.18 \\
Fusariumo.f. sp. pisi & 27.86 & 48.57 & 60.48 & 72.62 & 78.57 & 81.71 \\
Fusarium graminearum 91 & 32.77 & 63.87 & 81.51 & 86.97 & 91.60 & $\mathbf{9 2 . 8 6}$ \\
Fusarium graminearum 156 & 49.13 & 77.39 & 82.61 & 85.22 & 90.00 & $\mathbf{9 2 . 1 7}$ \\
Fusarium culmorum 124 & 58.67 & 71.69 & 76.91 & 79.33 & 81.73 & 84.67 \\
Fusarium culmorum 319 & 51.63 & 65.69 & 77.15 & 86.18 & 91.22 & $\mathbf{9 2 . 6 8}$ \\
Fusarium culmorum T7 & 53.25 & 60.57 & 71.54 & 80.49 & 86.59 & $\mathbf{9 1 . 4 6}$ \\
Fusarium culmorum BTCR & 39.22 & 56.86 & 82.35 & 84.71 & 92.94 & $\mathbf{9 4 . 1 2}$ \\
\hline
\end{tabular}

Bold values indicate the highest inhibition percentage values recorded

The radial mycelial growth was measured 6 days after inoculation (the data reported are the percentage inhibition \%) 
cis-8-acetoxychrysanthenyl acetate) or to a synergic effect of some constituents. Strains of $F$. graminearum and $F$. culmorum were susceptible to Tea tree EO (Terzi et al. 2007). Comparing to the study of Cakir et al. (2005), the EO of Hypericum linarioides had a weak activity on $F$. culmorum with inhibition percentage of $13.6 \%$ at $5 \mathrm{mg} / \mathrm{mL}$. In another study the Elettaria cardamomum EO had an important activity against $F$. graminearum $(90 \pm 1.3 \%$ at 3000 ppm) using the inverted Petri dish method (Singh et al. 2008).

The EO of A. graveolens aerial parts have a strong activity against Alternaria spp. and moderate activity against penicillium expansum with inhibition rate of $100 \%$ and $74.63 \%$, respectively at $0.2 \%(\mathrm{v} / \mathrm{v})$ of the oil (Znini et al. 2011). The EO of Schinus spp. and Thyme have also a strong activity against $F$. graminearum (Sampietro et al. 2014).

\section{Anticancer activity}

The results for cell growth inhibition by A. graveolens EO against Rat pheochromocytoma (PC12) and human liver carcinoma (HepG2) cell lines for various concentrations are shown in Figs. 1 and 2, respectively. This experiment shows that the EO of $A$. graveolens has an important activity against PC12 cell line comparing to the positive control. The activity against HepG2 cell line was less important at low concentrations but at $100 \mu \mathrm{g} / \mathrm{mL}, 82.98 \%$ of cells growth was inhibited. This activity could be due to their major components (cis-chrysanthenyl acetate and cis-8-acetoxychrysanthenyl acetate) or to a synergic with other components. Many species of Asteraceae (Matricaria chamomilla L., Artemisia desertorum L., Artemisia chamaemelifolia Vill.) are known for their anticancer activity (regarding their EOs) (Lesgards et al. 2014).

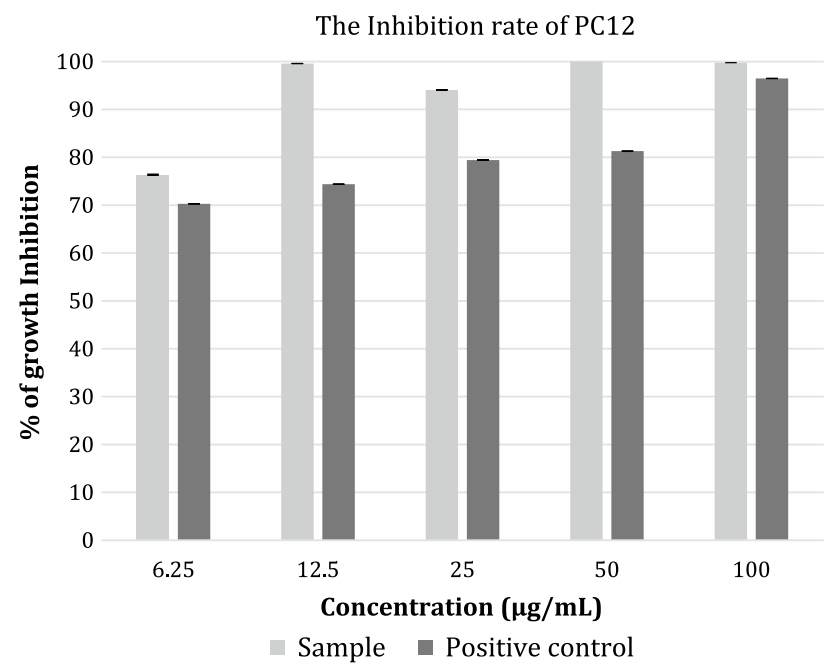

Fig. 1 Anticancer activity of A. graveolens flowers essential oil against PC12 cell lines

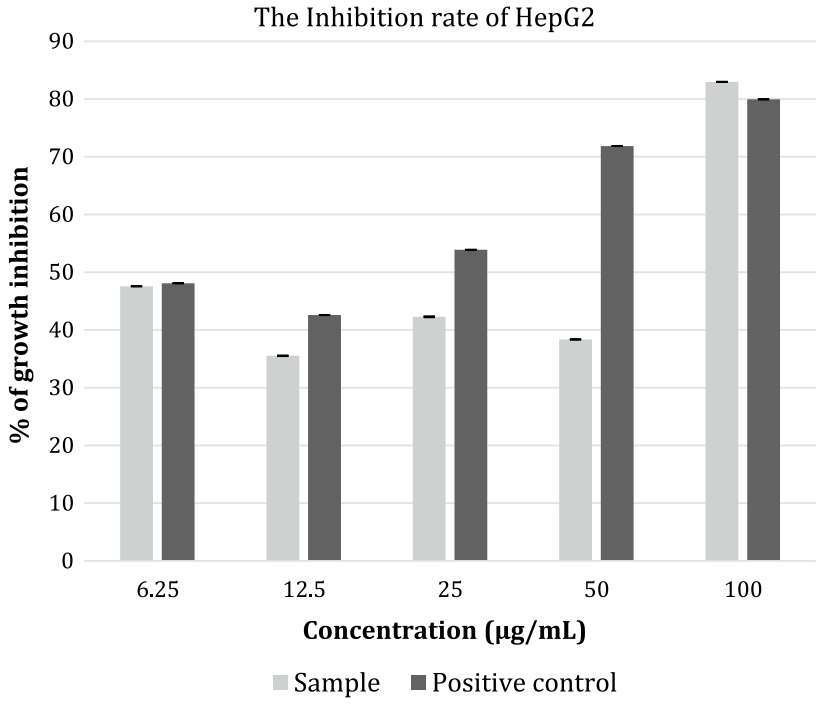

Fig. 2 Anticancer activity of A. graveolens flowers essential oil against HepG2 cell lines

The concentrations providing $50 \%$ of cell growth inhibition were less than $6.26 \mu \mathrm{g} / \mathrm{mL}$ for the PC12 cell line and more than $50 \mu \mathrm{g} / \mathrm{mL}$ for the HepG2. The results obtained by Wang et al. (2012) showed that the human hepatocellular liver carcinoma cell line (Bel-7402) were the most resistant to Rosmarinus officinalis L. EO and its major components among the tested cancer cell lines; however EO from Artemisia indica (Asteraceae) have a strong toxic effect on liver cancer cell lines HepG2 (Rashid et al. 2013).

\section{Conclusion}

The chemical composition of A. graveolens (Forssk) flowers essential oil was determined. The results showed two major components: $c i$-chrysanthenyl acetate and the cis-8-acetoxychrysanthenyl acetate. Moreover, we found for the first time some interesting antifungal and anticancer activities suggesting the presence of very active components in this EO. Further studies to elucidate the mechanisms of action, and the possible compounds involved in these activities will be undertaken.

Acknowledgements We thank Ms Sihem Touati for her help as well as the'Unité de Recherche Mycologie et Sécurité des Aliments' MycSa of Bordeaux for their kind help and suggestions.

\section{Compliance with ethical standards}

Ethical statement The study was conducted following the approval by the Institutional Animal Ethical Committee of Amar Télidji University, Laghouat, Algeria. 
Conflict of interest The authors declare that there is no conflict of interests regarding the publication of this paper.

\section{References}

Adorjan B, Buchbauer G (2010) Biological properties of essential oils: an updated review. Flavour Fragr J 25:407-426

Alilou H, Asdadi A, Hassani LI, González-Mas C, Blázquez MA, Akssira M (2014) Antifungal and antioxidant activity of Asteriscus graveolens subsp. odorus essential oil. J Nat Sci Res 4:1-10

Aoudou Y, Léopold TN, Michel JDP, Franccedil E, Moses MC (2010) Antifungal properties of essential oils and some constituents to reduce foodborne pathogen. J Yeast Fungal Res 1:001-008

Avlessi F, Dangou J, Wotto VD, Alitonou GA, Sohounhloue DK, Menut C (2004) Propriétés antioxydantes de l'huile essentielle des feuilles de Clausena anisata (Wild) Hook. C R Chim 7:1057-1061

Bakkali F, Averbeck S, Averbeck D, Idaomar M (2008) Biological effects of essential oils-a review. Food Chem Toxicol 46:446-475

Bekhechi C, Atik-Bekkara F, Abdelouahid D (2008) Composition et activité antibactérienne des huiles essentielles d'Origanum glandulosum d'Algérie. Phytothérapie 6:153-159

Buchanan BB, Gruissem W, Jones RL (2000) Biochemistry \& molecular biology of plants. American Society of Plant Physiologists, Rockville

Cabrera AC, Prieto JM (2010) Application of artificial neural networks to the prediction of the antioxidant activity of essential oils in two experimental in vitro models. Food Chem 118:141-146

Cakir A, Kordali S, Kilic H, Kaya E (2005) Antifungal properties of essential oil and crude extracts of Hypericum linarioides Bosse. Biochem Syst Ecol 33:245-256

Cheriti A, Saad A, Belboukhari N, Ghezali S (2007) The essential oil composition of Bubonium graveolens (Forssk.) Maire from the Algerian Sahara. Flavour Fragr J 22:286-288

Cristofari G, Znini M, Majidi L, Mazouz H, Tomi P, Costa J, Paolini J (2012) Chemical diversity of essential oils from Asteriscus graveolens (Forssk.) less.: identification of cis-8-acetoxychrysanthenyl acetate as a new natural component. Chem Biodivers 9:727-738

De Billerbeck V-G (2007) Huiles essentielles et bactéries résistantes aux antibiotiques. Phytothérapie 5:249-253

Dorman H, Deans S (2000) Antimicrobial agents from plants: antibacterial activity of plant volatile oils. J Appl Microbiol 88:308-316

El Ajjouri M et al (2008) Activité antifongique des huiles essentielles de Thymus bleicherianus Pomel et Thymus capitatus (L.) Hoffm. $\&$ Link contre les champignons de pourriture du bois d'oeuvre. Biotechnol Agron Soc Environ 12:345-351

Floris I, Carta C, Moretti M (1996) Activités in vitro de plusieurs huiles essentielles sur Bacillus larvae White et essai au rucher. Apidologie 27:111-119

International Union of Conservation of Nature IUCN (2005) A guide to medicinal plants in North Africa, 1st edn. IUCN Centre for Mediterranean Cooperation, Spain
Lesgards JF, Baldovini N, Vidal N, Pietri S (2014) Anticancer activities of essential oils constituents and synergy with conventional therapies: a review. Phytother Res 28:1423-1446

Marinelli E, Orzali L, Lotti E, Riccioni L (2012) Activity of some essential oils against pathogenic seed borne fungi on legumes. Asian J Plant Pathol 6:66-74

Marino M, Bersani C, Comi G (2001) Impedance measurements to study the antimicrobial activity of essential oils from Lamiaceae and Compositae. Int J Food Microbiol 67:187-195

Matusinsky P, Zouhar M, Pavela R, Novy P (2015) Antifungal effect of five essential oils against important pathogenic fungi of cereals. Ind Crops Prod 67:208-215

Melekmi N, Saad A, Belboukhari N, Cheriti A (2006) Antimicrobial activity of the essential oil of Bubonium graveolens. Annales de l'université de Bechar 2:22-26

Molyneux P (2004) The use of the stable free radical diphenylpicrylhydrazyl (DPPH) for estimating antioxidant activity. Songklanakarin J Sci Technol 26:211-219

Mosmann T (1983) Rapid colorimetric assay for cellular growth and survival: application to proliferation and cytotoxicity assays. J Immunol Methods 65:55-63

Prieto P, Pineda M, Aguilar M (1999) Spectrophotometric quantitation of antioxidant capacity through the formation of a phosphomolybdenum complex: specific application to the determination of vitamin E. Anal Biochem 269:337-341

Rashid S, Rather MA, Shah WA, Bhat BA (2013) Chemical composition, antimicrobial, cytotoxic and antioxidant activities of the essential oil of Artemisia indica Willd. Food Chem 138:693-700

Sampietro DA, Belizana M, Baptista Z, Vattuone MA, Catalán C (2014) Essential oils from Schinus species of northwest Argentina: composition and antifungal activity. Nat Prod Commun 9:1019-1022

Singh G, Kiran S, Marimuthu P, Isidorov V, Vinogorova V (2008) Antioxidant and antimicrobial activities of essential oil and various oleoresins of Elettaria cardamomum (seeds and pods). J Sci Food Agric 88:280-289

Strange RN, Scott PR (2005) Plant disease: a threat to global food security. Annu Rev Phytopathol 43:83-116

Terzi V, Morcia C, Faccioli P, Vale G, Tacconi G, Malnati M (2007) In vitro antifungal activity of the tea tree (Melaleuca alternifolia) essential oil and its major components against plant pathogens. Lett Appl Microbiol 44:613-618

Vidic D, Ćavar Zeljković S, Dizdar M, Maksimović M (2016) Essential oil composition and antioxidant activity of four Asteraceae species from Bosnia. J Essent Oil Res 28:445-457

Wang W, Li N, Luo M, Zu Y, Efferth T (2012) Antibacterial activity and anticancer activity of Rosmarinus officinalis L. essential oil compared to that of its main components. Molecules 17:2704-2713

Zhiri A (2006) Les huiles essentielles un pouvoir antimicrobien avéré. Nutra News Sci

Znini M, Cristofari G, Majidi L, Mazouz H, Tomi P, Paolini J, Costa J (2011) Antifungal activity of essential oil from Asteriscus graveolens against postharvest phytopathogenic fungi in apples. Nat Prod Commun 6:1763-1768 